1. Michael Henry MILLGATE, M.A. (Cantab.): at present doing post-graduate research in American literature at the University of Leeds. (W.E.A. TutorOrganiser in South Lindsey, Lincolnshire, 1953-6; Teaching Fellow, Department of English, University of Michigan, 1956-7.)

2. Bars Hill, Cowes, Isle of Wight.

4. "A good word for England", Partisan Review, Summer 1957; "Workers' Education in the United States", The Highway. The Journal of the Workers' Educational Association, Decernber 1957.

5. Research on "The American Bureaucratic Novel". Working on a book of American impressions.

1. Walter Edward MINCHINTON, B.Sc.Eson.: Lecturer in Social and Economic History, University College of Swansea.

3. Honours course in American history, 1800-1939. Has plans f or a Special Subject on England and the American colonies in the eighteenth century.

5. Interested in the history of the American colonies. Has a study of AngloAmerican commerce in preparation.

1. William V. WALLACE, M.A. (Glasgow), M.A. (London): Assistant in History, University of Aberdeen. (Part-time Lecturer in History, Queen Mary College, London, 1955-7; Lecturer in History, University of Pittsburgh, 1953-4.)

5. Contemporary history, especially the Munich era.

Professor R. L. BRETT (Department of English, University of Hull) and Mr. Louis BILLINGTON (Research student, Department of History, University of Bristol) have also joined the Association. We hope to publish details of their interests and careers in a future issue of the Bulletin.

\title{
JOHN BARTLET BREBNER
}

The death of John Bartlet Brebner removes from the community of AngloAmerican historical scholarship a beloved and respected figure who will be especially mourned in the British Association for American Studies, not only because many of us were fortunate enough to come within the circle of his friendship, but because he was, in a sense, the Association's prophet.

"Bart" Brobner was one of those rare individuals whose academic interests and personal career are so satisfyingly interwoven as to result, not only in sound learning, but in wisdom; and he was one of a very small number to acquire such stature in the field of North Atlantic history. Born a Canadian of Scottish ancestry, the son of the Registrar of Toronto University, he served during the 1914-18 War in the British Army. As an ex-serviceman, he went up to St. John's College, Oxford where he read history with G. N. Clark, rowed in the first eight, and saw something of the world of post-war London. After returning to the University of Toronto, one of a distinguished vintage of young graduate students and lecturers which included Lester Pearson and D. G. Creighton, he joined the staff at Columbia University in 1927; and from this New York vantage point he mastered the broad sweep of Atlantic history.

It was characteristic of the man that his scholarship should be an integral part of his own personal explorations in the Atlantic world; and as a result, his historical writing has a satisfying unity. In the light of what was to come, his first book, New England Outpost: Acadia before Conquest, published in 1927, like his third, The Neutral Yankees of Nova Scotia, published a decade later, was a deceptively modest study in the interplay of Yankees and Canadians in the colonial period. Six years later came The Explorers of North America, in which he developed that conception of, and technique for writing, history as the movement of peoples in a geographic environment. which he was to perfect in his last two works. In the late thirties Brebner undertook to finish and edit the manuscript of Marcus Hansen's The Mingling of the Canadian and Amorican Peoples, which Hansen's prenature death had left incomplete. This was a labour of piety; for Brebner, always generously responsive, cherished his intellectual, as well as his personal friendships. He ragarded himself in a sense as the disciple of Hansen, that great man whose death robbed migration studies of the full impact of his power; and it was charactoristic of Brebner that he should make Hansen the point of departure for his lectures to the first Fulbright Conference on Anorican Studies at Cambridge. 
Brebner's chef d'ocuvre, however, was North Atlantic Triangle: The Interplay of Canada, the United States and Great Britain, published in 1945. The Priangle, as he always called it, was a difficult book to write, and, indeed, the original droft was completely re-written; but it reveals Brebner's full powers as a historian. It is ospecially distinguished by his gift, also displayed in his loctures, for combining significant event and concrete detail in an illuminating narrative which builds up to a poworful synthesis. In treating the North Atlantic as a single, regional entity, he broke through the conventional rigidities of economics, politics and diplomacy to achieve a new interpretation of which Canadian, American and British historians must take account. In an age when works of synthesis are at a discount, North Atlantic Triangle has nevor quite achievod the contral position which it deserves. It. recently figured in a symposium on important but neglected books, a fact which gave its author wry enjoyment; but it is a stayer in the historical stakes, and its value will bo enhanced with the years.

Since the War, as Gouverneur Morris Professor of History at Columbia, Brebnor turned his attention increasingly to the British apex of his triangle, concerning himself with Benthamism and then, at the time of his death, with writing another large-scale work. This was to be a general history, as he put it, of "the manifold adaptations to industrialization of British society since the middle of the eighteenth century". This promised to be a characteristically bold, ambitious and imaginative synthesis such as the world sorely needs and such as Brebner had the rare combination of courage and ability to write. Had he lived to carry through this project, he would have completed a corpus of writing which, even unfinished, is a lasting and inspiring memorial.

Yet the library shelves do not give one the full measure of him. The thrust of his curiosity, his wide acquaintance in the world of affairs, and, above all, his generous and patient guidance to colleagues and students, combined to create a personal ambience which may be measured by the sense of loss now felt by a multitude of individuols who had come to rely on his counsel, support and genial cornpanionship.

He moved easily on both sides of the Atlantic and, in latter years, made himself particularly at home in this country. He sent a succession of graduate students to London University, where he maintained close relations with $H$. $L$. Beales and others, and he was almost as familiar a figure at the Anglo-American Historical Conference in London as he was in the British Studies Association in Hew York. In 1952, when the first, experimental, Fulbright Conference on American Studies was organized at Cambridge, it was a natural decision to choose "The Atlantic Community" as its theme and to invite Brebner to play the leading role in a distinguished cast of Anerican scholors. Only those who knew his renarkable sense of occasion could have anticipated the brilliant way in which he responded to the opportunity, not only with lectures and sominars which did much to give the Conference intellectual conerence, but with his pastoral gifts. His interest in the ideas and personalities of the predominantly youthful members of the Conference was genuine and inaginative, and in many cases it was maintained and strengthened by subsequent contact. He was, for example, a most painstaking and sympathetic reader of even the most tentative manuscript. Later, in his apartment on Columbia Heights overlooking Manhattan, or in his Carnbidge rooms, his conversation continued to reveal an unflagging interest in the individuals all over Britain who were struggling with the problens of teaching Anorican subjects; and his unassuming, wise advice during the fornative stages of the B.A.A.S. was invaluable.

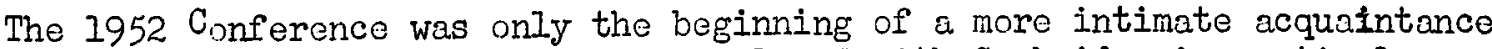
in Britain with American studies in general and with Cambridge in particular. It was inevitable that Brebner should return to Canbridge as Pitt Professor of American History and Institutions, the chair which he held witl distinction in the year 1954-55. His genius for accommodating himself sensitively to the community in which he moved, whether it was the graduate club at Columbia, the Century Association in New York or the Athenaeum in London made him easily at home in a Cambridge college, and during the first weeks of his residence at the 152 Conference, through the year of his Fellowship, and in his subsequent long vacation visits he bocame, dospite the painful illness of the last few years, a familiar, and much loved, spirit in St. John's College, with which he preserved a unique personal connection. 
Yet Brebner had nothing of the uncritical anglo-phile about him. After a life lived in action and in study in the North Atlantic triangle, he was conscious, to a degree which gave him wisdon, of tensions, as well as affinities, in the interplay of North Arerica and Britain, of the contrast between what he liked to call the "populistic denocracy" of the United States and the "paternalistic democracy" of Britain, as well as of the subtle "complementarity", as he termed it, in Anglo-Anerican relations. These, and the even more subtle tensions between the Canadian and the American character, were in Brebner in such perfect equilibrium that he was able to preserve a remarkable integrity. He was a living embodiment of the idea of an Atlantic community.

Brebner was one of the committee which planned the degree congregations celebrating the 200th anniversary of the foundation of Columbia University and which, at the height of the McCarthy inquisition, took as its theme "Man's Right to Knowledge and the Free Use Thereof". It was fitting that at the last of those brilliant congregations, held in the Cathedral Church of St. John the Divine before an audience which included Queen Elizabeth, the Queen Mother, Dr. Adanauer and fidlai Stevenson, Brebner should act as Public Orator, having flown from Cambridge for the occasion. The subject of his address was "Humility". In the words of his friend H. L. Beales, "Bart' gave us a glimpse, so perfect in its poise and selfless simplicity, of one of the eternal verities."

FRANK THISTLETHWAITE. 